УДК 336.7

https://doi.org/10.52058/2708-7530-2021-11(17)-340-350

Чернишова Ольга Борисівна кандидат економічних наук, доцент, Одеський торговельно-економічний фаховий коледж Київського національного торговельно-економічного університету, вул. 25 Чапаєвської дивізії, 6, м. Одеса, 65070, тел.: (067) 282-15-10, e-mail: Chernyshova_o@ukr.net, https://orcid.org/0000-0002-5781-8044

Ольшанська Марія Володимирівна кандидат економічних наук, доцент, доцент кафедри обліку та аналізу, Національний університет «Львівська політехніка», вул. Митрополита Андрея, 5, м. Львів, 79013, тел.: (067) 673-36-76, e-mail: mariia.v.olshanska@lpnu.ua, https://orcid.org/0000-0002-5353-4212

Кузьменко Олена Юріївна старший викладач кафедри економіки та морського права, Херсонська державна морська академія, пр. Ушакова, 20, м. Херсон, 73000, тел.: (099) 942-70-80, e-mail: panasenkova.elen@gmail.com, https://orcid.org/0000-0001-7542-7322

\title{
ПЕРСПЕКТИВИ ВПРОВАДЖЕННЯ ВІРТУАЛЬНИХ ГРОШЕЙ В УКРАЇНI
}

Анотація. У статті розкрито перспективи впровадження віртуальних грошей в Україні. Віртуальні гроші функціонують у цифровому форматі, а їх розрахунковою одиницею виступає ідентифікація клієнта. Однією із розвинених форм віртуальних грошей виступають криптовалюти. Основною одиницею криптовалюти виступає код, який одержує користувач, використовуючи комп'ютерні потужності. Криптовалюти нічим не підкріплюються, тому їхня вартість піддержується тільки за рахунок зростання попиту та складності виробництва нового коду кожної нової криптовалюти. Станом на сьогодні у світі функціонує приблизно 1500 видів криптовалют. Практика показує, що нині в Україні немає єдиної позиції стосовно правового статусу та державного регулювання віртуальних грошей. За даними Global Crypto Adoption Index 2021 Україна посіла 4 місце у цьому рейтингу, що свідчить про те, що в Україні значними темпами зростає попит на криптовалюту як один із видів віртуальних грошей. Україна, займаючи високі місця у рейтингу країн із значними обсягами операцій із криптовалютами, входить до списку країн, що займають високі позиції у рейтингу прибутків від операцій із криптовалютами. Ринок віртуальних грошей в Україні, незважаючи на неналежні умови правового, і державного регулювання зокрема, зростає. Україна займає провідне місце у світі серед інших країн, де обороти криптовалюти, як одного із видів валютних грошей, є доволі значними. 
Кількість користувачів криптовалюти в Україні з кожним роком зростає, однак юридичних осіб, що займаються офіційно таким видом діяльності, не зареєстровано. Станом на сьогодні в Україні немає єдиної позиції стосовно правового статусу та державного регулювання віртуальних грошей. Зважаючи на те, що відбулись певні спроби до легалізації ринку віртуальних грошей в Україні, до прикладу, ухвалення Закону України «Про віртуальні активи», однак згодом було накладено право вето на нього Президентом України.

Ключові слова: віртуальні гроші, криптовалюта, біткоїн, правове регулювання, операції з купівлі/продажу, ринок віртуальних грошей.

Chernyshova Olga Borysivna Candidate of Economic Sciences, Associate Professor, Odessa Trade and Economic Vocational College of Kyiv National University of Trade and Economics, 25 Chapaev Division St., 6, Odessa, 65070, tel.: (067) 282-15-10, e-mail: Chernyshova_o@ukr.net, https://orcid.org/0000-0002$5781-8044$

Olshanska Maria Volodymyrivna Candidate of Economic Sciences, Associate Professor, Associate Professor of Accounting and Analysis Department, Lviv Polytechnic National University, Metropolitan Andrew St., 5, Lviv, 79013, tel.: (067) 673-36-76, e-mail: mariia.v.olshanska@lpnu.ua, https://orcid.org/0000-0002$5353-4212$

Kuzmenko Olena Yuriyivna Senior lecturer of the Department of Economics and Maritime Law, Kherson State Maritime Academy, Ushakov Ave., 20, Kherson, 73000, tel.: (099) 942-70-80, e-mail: panasenkova.elen@gmail.com, https://orcid.org/0000-0001-7542-7322

\section{PROSPECTS FOR THE INTRODUCTION OF VIRTUAL MONEY IN UKRAINE}

Abstract. The article reveals the prospects for the introduction of virtual money in Ukraine. Virtual money operates in digital format, and their unit of account is customer identification. Cryptocurrencies are one of the developed forms of virtual money. The basic unit of cryptocurrency is the code that the user receives using computer power. Cryptocurrencies are not supported by anything, so their value is maintained only by increasing demand and the complexity of producing a new code for each new cryptocurrency. As of today, there are approximately 1,500 types of cryptocurrencies in the world. Practice shows that today in Ukraine there is no single position on the legal status and state regulation of virtual money. According to the Global Crypto Adoption Index 2021, Ukraine took 4th place in this ranking, which indicates that in Ukraine the demand for cryptocurrency as one of the types of virtual money is growing rapidly. Ukraine, occupying high places in the 
ranking of countries with significant volumes of operations with cryptocurrencies, is included in the list of countries occupying high positions in the ranking of profits from operations with cryptocurrencies. The market of virtual money in Ukraine, despite the inadequate conditions of legal and state in particular, regulation is growing. Ukraine is a world leader among other countries where the turnover of cryptocurrency, as a type of currency, is quite significant. The number of cryptocurrency users in Ukraine is growing every year, but no legal entities are officially engaged in this type of activity. As of today, there is no single position in Ukraine regarding the legal status and state regulation of virtual money. Due to the fact that there were some attempts to legalize the virtual money market in Ukraine, for example, the adoption of the Law of Ukraine "On Virtual Assets", but later the President of Ukraine vetoed it.

Keywords: virtual money, cryptocurrency, bitcoin, legal regulation, purchase / sale operations, virtual money market.

Постановка проблеми. Початок XXI століття йменується століттям розвитку інформаційних технологій, який в період останніх років демонструє значне зростання. Мережа Інтернет виступає ключовою складовою сучасного життя. Інформація спільно із торгівлею та консультаційною діяльністю $є$ сьогодні у порівнянні з початком XXI століття ще доступнішими, а все це завдяки розвитку мережі Інтернет. Реалізувати товари, а у деяких випадках надавати послуги, сьогодні можливо в онлайн-режимі. Завдяки такій організації збуту товарів та надання послуг значно економляться кошти та час як покупців, так і продавців. Явно позитивним ефектом такого процесу виступає доступність мережі Інтернет все більшій кількості користувачів.

Варто зазначити також вплив мережі Інтернет на розвиток віртуальних грошей, адже зростання масштабності онлайн-ринку останнім часом є доволі очевидним. Розвиток віртуальних грошей все більше підвищує зручність та рівень безпеки користувачів цих грошей, адже, як показує практика, нині на ринку віртуальних грошей вже створені та ефективно функціонують електронні гаманці.

Аналіз останніх досліджень і публікацій. Над проблематикою впровадження віртуальних грошей в економіку України працювали та продовжують працювати такі відомі дослідники як С. Аржевітін, С. Волосович, О. Григоревська, Г. Карчева, О. Куриліна, В. Мандрик, К. Черевко та інші.

Так, С. Волосович [1] зазначає, що віртуальні гроші, 3 однієї сторони виступають головною фінансовою інвестицією, а з іншої - інструментом, що призначається для відмивання коштів та фінансування певного роду тероризму, злочинним елементом якого виступає ухилення від контролю регулятора і ситуації накладення санкцій. На думку науковця, віртуальні гроші доцільно поділяти на три такі види, як: 
- закрита схема віртуальних грошей, що не стосується задіяння у реальну економіку;

- схема віртуальних грошей, яку формують єдинонацілені потоки придбання таких грошей через реальні гроші в межах певного установленого напрямку;

- схема віртуальних грошей, що побудована на базі двосторонніх потоків, де віртуальні гроші купляються та/чи продаються у відповідності до ставки плаваючих валютних курсів.

Виділяючи такі три категорії віртуальних грошей за схемами їх формування, С. Волосович [1] зауважує, що лише третя схема віртуальних грошей, за якої віртуальні гроші купляються та/чи продаються за відповідними ставками плаваючих курсів, має право на належне функціонування.

Своєю чергою, А. Малиновська [2] наголошує на тому, що вагому роль у формуванні національних віртуальних грошей виконують зацікавлені країни, що перебувають під загрозою накладення на них міжнародних санкцій. Ці країни вбачають деякі можливі труднощі, що існують у міжнародній банківській системі. Деякі країни вбачають таку позицію, за якої реалізація подібних інноваційних цифрових проектів може стати приводом для безповоротного удосконалення міжнародної валютної системи, що зараз існує. Щоб стати власником віртуальних грошей, треба пройти один із зазначених нижче шляхів. Перший шлях полягає у придбанні на спеціалізованій біржі таких грошей, другий - у вигляді виграшу за результатами гри, третій - у вигляді одержання як винагороди за послуги, що було надано, четвертий - за реалізацію товарів, а п'ятий - за здобуття таких грошей через проходження процедури mining.

Обираючи останній шлях, слід зазначити, що процедура mining дає можливість одержати невеликий дохід, а на чистий прибуток, що одержаний від такої процедури, чинять вплив витрати на електроенергію і обладнання. Щоб реалізувати процедуру mining, потрібно якнайперше мати у наявності спеціалізований графічний процесор (GPU) чи спеціалізовану інтегральну схему (ASIC). Визначальне значення також відіграє достатня кількість засобів для здійснення охолодження обладнання, наявність постійного підключення до мережі Інтернет, законний пакет програмного забезпечення, що є потрібний для реалізації такої процедури, а також членство у онлайн-обміннику [2].

Незважаючи на те, що досить багато досліджень націлені на вивчення питань впровадження валютних грошей, не до кінця розкритими залишаються такі питання з точки зору перспектив їх впровадження в Україні.

Мета статті націлена на розкриття перспектив впровадження віртуальних грошей в Україні.

Виклад основного матеріалу. Враховуючи інформацію, подану у [3], віртуальні гроші являють собою розрахункову грошову одиницю, яка не $\epsilon$ відповідна ніякій матеріальній грошовій одиниці. Віртуальні гроші 
функціонують у цифровому форматі, а їх розрахунковою одиницею виступає ідентифікація клієнта. Емісія віртуальних грошей генерується завдяки математичному методу. Емітентами віртуальних грошей можуть бути співтовариства громадян. Віртуальні гроші наділені повною децентралізацією. У віртуальних грошах присутня повністю прозора система розрахунків. Контроль над віртуальними грошима проводиться в рамках угод у цій системі.

Однією із розвинених форм віртуальних грошей виступають криптовалюти. Їхня назва похідна від методу здійснення записів щодо випуску та обігу такої форми грошей, тобто від методу криптографії чи методу шифрування. Перша криптовалюта виникла в 2009 році та мала назву біткоїн. Однак, не враховуючи появу нових криптовалют, серед яких Ripple, Dogecoin, Nxt, Litecoin, BitSharesX, Darkcoin, Peercoin, MaidSafeCoin тощо, станом на сьогодні біткоїн все-таки є однією із найпоширеніших і водночас однією із «найдорожчих» цифрових монет. Так, у 2015 році капіталізація біткоїна становила 4,9 млрд. доларів. Оборот біткоїна, так само, як інших криптовалют, базується на технології блокчейн, тобто на ланцюжках блоків із даними щодо транзакції. Такі дані щодо транзакцій зберігаються на усіх комп'ютерах цієї системи, а також взаємопов'язані між собою, оскільки кожен блок включає посилання на блок, який був перед ним [4].

Ведучи мову про віртуальні гроші, зокрема про криптовалюту, слід першочергово розглянути технічну складову такого явища. Основною одиницею криптовалюти виступає код, який одержує користувач, використовуючи комп'ютерні потужності. У випадку проведення такої операції код може бути переданий покупцеві криптовалюти у вигляді відкритого коду. Що стосується системи виробництва криптовалюти, а також специфіки здійснення угод за ними, то цей процес $є$ досить складним, тому що створює ряд додаткових проблем у напрямку їх правового регулювання.

За своєю природою криптовалюти не $\epsilon$ грошима. Криптовалюти нічим не підкріпляються, тому їхня вартість піддержується тільки за рахунок зростання попиту та складності виробництва нового коду кожної нової криптовалюти. У хід регулювання обігу криптовалют не залучаються ані внутрішні, ані зовнішні керуючі органи. Така ситуація свідчить про те, що криптовалюта може бути одним із шахрайських інструментів, що функціонує 3 ціллю незаконного оволодіння чужими коштами.

Криптовалюта як вид віртуальних грошей має свої особливості, детальний огляд яких представлений на рис. 1. 


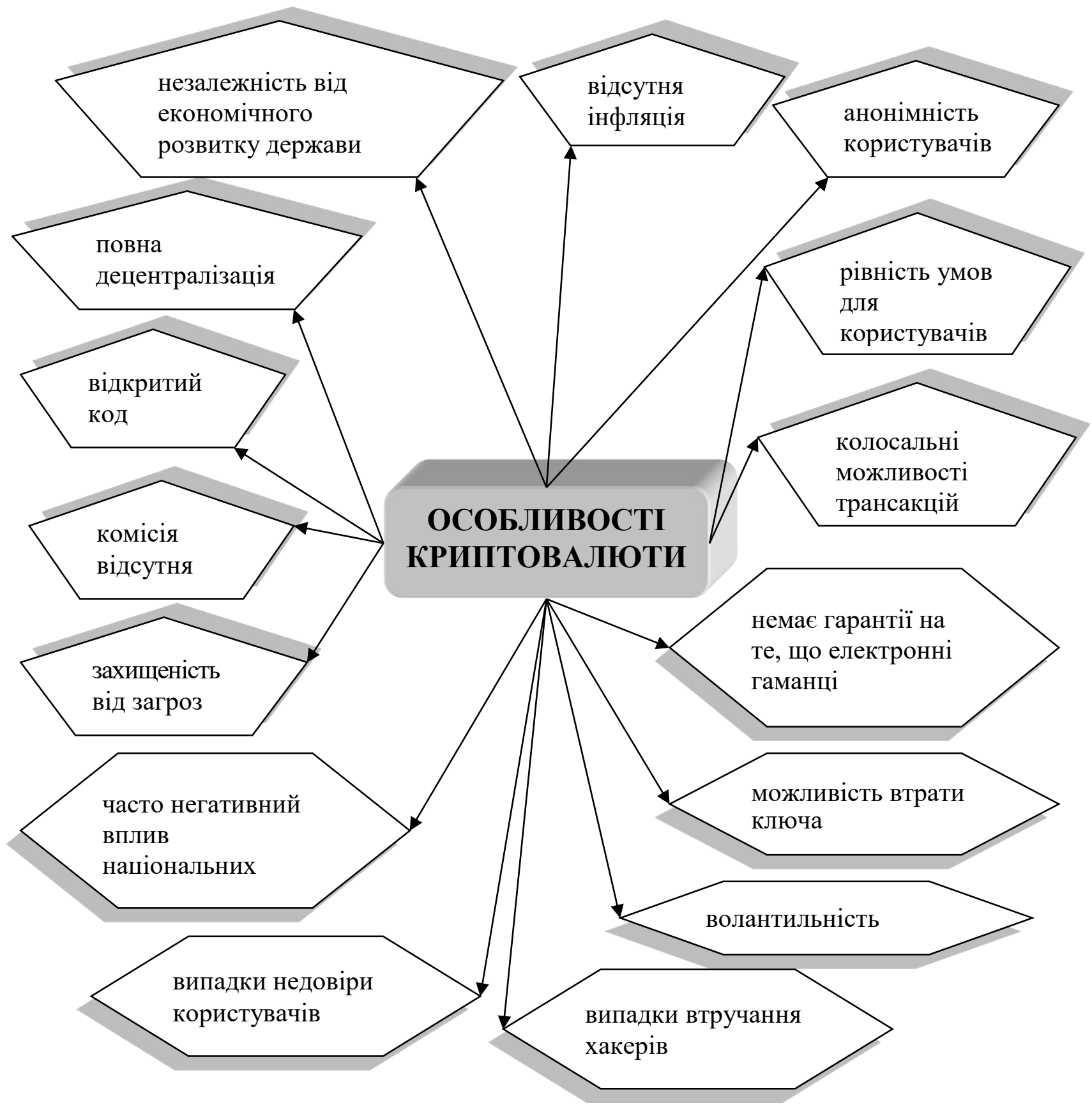

Рис. Особливості криптовалюти як виду віртуальних грошей Джерело: побудовано авторами на основі [5]

Станом на сьогодні у світі функціонує приблизно 1500 видів криптовалют. Ці валюти дещо відрізняються одна від одної, але і водночас мають деякі спільні риси [6]. Як зазначалось вище, однією із найпоширеніших та досить популярних криптовалют $\epsilon$ біткоїн. За програмою генерації i транзакції біткоїнів, їх функціонування наділене усіма необхідними ознаками, що притаманні світовим валютам. Однак треба зауважити, що біткоїни $\epsilon$ кількісно обмежені, оскільки їх налічується 21000000 монет [7]. 
Біткоїни можуть обмінуватись на традиційні види грошових одиниць. Цінність біткоїнів як віртуальних грошей установлюється ринком, де попит та пропозиція виступають інструментами визначення цінності цих грошей. 3 огляду на те, слід зазначити, що емісія є застрахованою від індивідуального втручання, а також від регулювання. Це свідчить про те, що кількість монет спочатку установлюється, де швидкість випуску трансакції знаходяться у прямій залежності від споживачів цих віртуальних грошей. Із зростанням кількості користувачів такої системи, в якій генеруються нові одиниці цієї валюти, віртуальні гроші можуть знецінюватись. Генерування кожної із монет біткоїнів проводиться користувачами, а якщо говорити точніше, то за допомогою комп'ютерних потужностей, які використовують користувачі. Головного засадою функціонування криптовалюти виступає те, що транзакції за рахунками відображаються даними на загальній платформі. Це, своєю чергою, дає можливість оперативно відстежити операції, що проводяться усіма користувачами.

У контексті розкриття перспектив впровадження віртуальних грошей в Україні доцільно розглянути правову природу регулювання процесу їх функціонування.

Практика показує, що нині в Україні немає єдиної позиції стосовно правового статусу та державного регулювання віртуальних грошей. Однак, тут доцільно зауважити, що відсутність єдиного підходу до правового статусу та неналежне державне регулювання аж ніяк не впливають на те, що Україна є одним із світових лідерів, де індикатор капіталу, що інвестується у криптовалюти, займає доволі значну частку у ВВП країни.

В останні роки спостерігається доволі значний сплеск зацікавленості правоохоронних органів криптовалютами. Відомою є ситуація, що відбулась у 2017 році. Так, правоохоронними органами, зокрема Національною поліцією і СБУ було виявлено на території Інституту електрозварювання імені Патона у одному із приміщень цього Інституту біля 200 комп'ютерів, що незаконно були задіяні у процесах генерування криптовалюти «біткоїн». 3 огляду на те, Святошинським районним судом міста Києва було ухвалено постанову за цим інцидентом. У Постанові йшлося про те, що «видобуток» криптовалюти $\epsilon$ забороненим [8].

Ухвалення такої Постанови базується на положеннях на Закону України «Про Національний банк України». Так, згідно статті 32 3У «Про Національний банк України» [9] на території України забороняється випуск i обіг інших грошових одиниць, а також використання грошових сурогатів у вигляді засобів платежу. Однак тут слід зауважити певну неточність, оскільки криптовалюта не відноситься до сурогату.

Так, згідно положень Спільної заяви фінансових регуляторів щодо статусу криптовалют в Україні [10], фінансові регулятори України 
продовжують на постійній основі працювати над питанням правового статусу криптовалют і урегулювання операцій 3 криптовалютами на законодавчій основі. Як базу регулятори використовують інші країни, а також вираховують останні події, що спостерігались у розвитку віртуальних грошей. Основною ціллю урегулювання операцій із криптовалютами в Україні виступає забезпечення захисту прав споживачів, а також запобігання та протидія випадків відмивання коштів чи вчинення інших протиправних діянь. Спільною заявою фінансових регуляторів щодо статусу криптовалют в Україні передбачено також проведення ідентифікації суб'єктів, що здійснюють операції за криптовалютами, зокрема проведення фінансового моніторингу.

3 огляду на таку заяву, зміни, що повинні відбутись у законодавстві України, перш за все, мають базуватись на результатах проведеного глибокого та детального дослідження процесу операцій із криптовалютами, його впливу на ситуацію на фінансових ринках.

За даними Global Crypto Adoption Index 2021, Україна посіла 4 місце у цьому рейтингу. Це свідчить про те, що в Україні значними темпами зростає попит на криптовалюту як один із видів віртуальних грошей (табл. 1).

Таблиия 1

Оціночні показники України на ринку криптовалюти за даними Global Crypto Adoption Index

\begin{tabular}{|l|c|c|}
\hline Показники & 2020 & 2021 \\
\hline Ранг & 1 & 4 \\
\hline $\begin{array}{l}\text { Індексна } \\
\text { оцінка }\end{array}$ & 1 & 0,29 \\
\hline
\end{tabular}

Джерело: побудовано за даними [11-12].

Що стосується прибутковості від операцій із віртуальними грошима, то тут треба відзначити те, що Україна, займаючи високі місця у рейтингу країн із значними обсягами операцій із криптовалютами, входить до списку країн, що займають високі позиції у рейтингу прибутків від операцій із криптовалютами. Так, до прикладу, на рис. 1 представлено, що за період 2020 року Україна увійшла у топ-10 країн, де прибутки від операцій із криптовалютами, зокрема із операціями про біткоїн, становили 400 млн. дол. США. 


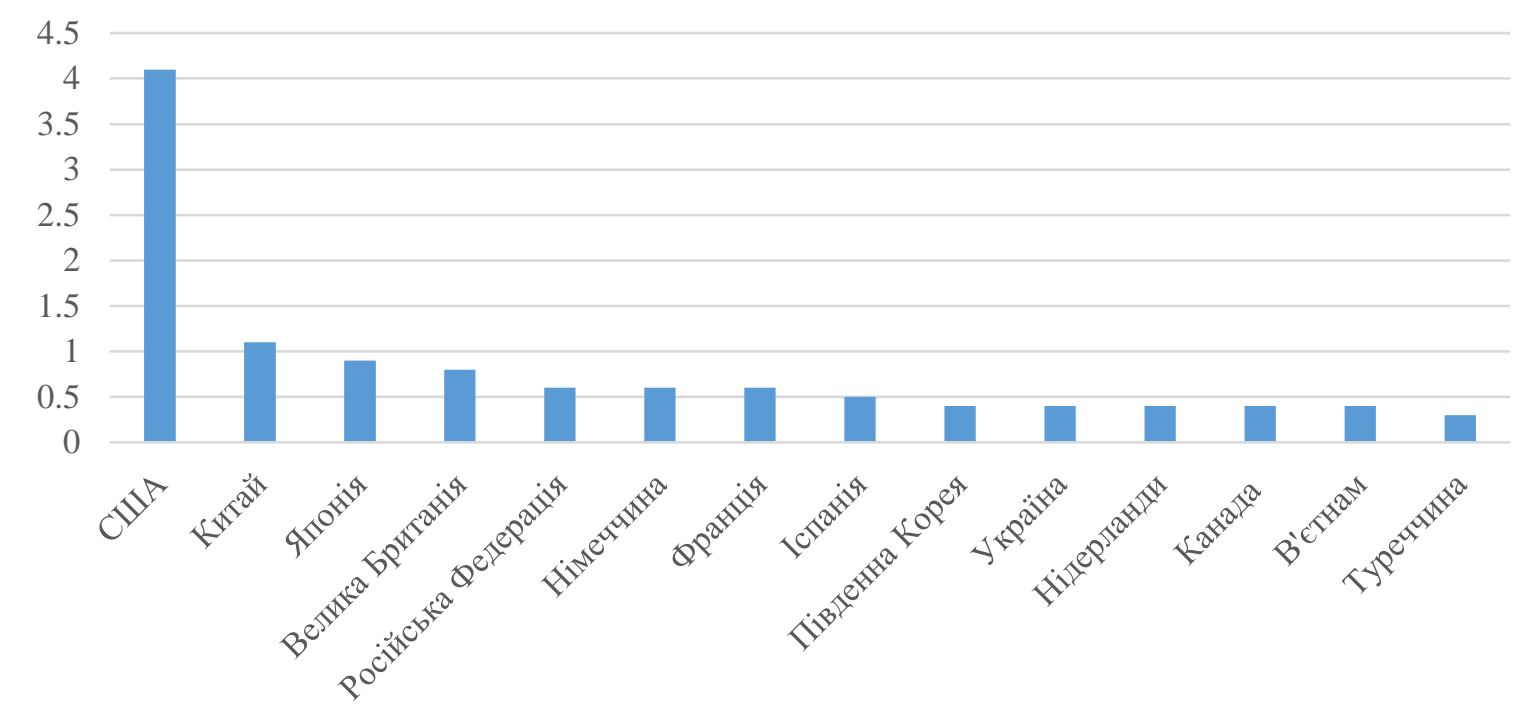

Рис. 1. Прибуток провідних країн за операціями із біткоїн на ринку віртуальних грошей

Джерело: побудовано за даними [13].

Акцентуючи увагу на подальших перспективах впровадження віртуальних грошей в Україні, слід зауважити, що у вересні 2021 року Верховною Радою України було прийнято Закон України «Про віртуальні активи». У відповідності до цього законом передбачено проведення легалізації віртуальних активів та легалізації бізнесу у цій сфері. Так закон $є$ базовим документом та установлює правовий статус віртуальних активів (віртуальних грошей). Однак, вже у жовтні 2021 Президентом України було накладено право вето.

Висновки. За результатами проведених досліджень встановлено, що ринок віртуальних грошей в Україні, незважаючи на неналежні умови правового, і державного регулювання зокрема, зростає. Україна займає провідне місце у світі серед інших країн, де обороти криптовалюти, як одного iз видів валютних грошей, $є$ доволі значними. Кількість користувачів криптовалюти в Україні з кожним роком зростає, однак юридичних осіб, що займаються офіційно таким видом діяльності, не зареєстровано.

Станом на сьогодні Україні немає єдиної позиції стосовно правового статусу та державного регулювання віртуальних грошей. Зважаючи на те, що відбулись певні спроби до легалізації ринку віртуальних грошей в України, до прикладу, ухвалення Закону України «Про віртуальні активи», однак згодом було накладено право вето Президента України.

Вважаємо за потрібно зазначити, що ринок віртуальних грошей в Україні доцільно все-таки легалізувати, але перед тим потрібно досконало вивчити та проаналізувати всі можливі шляхи недопущення негативних явищ, зокрема тих, що взаємопов'язані чи стосуються злочинної діяльності, у ході здійснення такої діяльності. Ринок віртуальних грошей має бути прозорим і не допускати 
ситуацій порушення прав як учасників цього ринку, так i держави, як основного державного регулятора.

\section{Лimepamypa:}

1. Волосович С.В. Віртуальна валюта: глобалізаційні виклики і перспективи розвитку. Науковий журнал «Економіка України». 2016. № 4(653). С. 68-78.

2. Малиновська А.М. Віртуальні валюти: поширення та передумови до визначення. Вісник економічної науки. 2019. № 2. С. 165-169.

3. Особливості функціонування віртуальних криптовалют: економічний аспект. http://www.global-national.in.ua/archive/14-2016/152.pdf

4. Рубанов П.М. Розмежування сутності понять «електронні гроші», «віртуальні гроші» та «криптовалюти». Ефективна економіка. 2015. № 4. http://www.economy.nayka.com.ua/ ?op $=1 \& \mathrm{z}=6026$

5. Віртуальні гроші в Україні: чи потрібно легалізувати криптовалюту. https://www.slovoidilo.ua/2019/11/19/pogljad/ekonomika/virtualni-hroshi-ukrayini-chypotribnolehalizuvaty-kryptovalyutu

6. COINCAP. https://coincap.io/

7. BITCOIN. https://bitcoin.org/uk/

8. В інституті Патона правоохоронці випадково натрапили на нелегальну «фабрику біткоїнів». ТCH. https://tsn.ua/ukrayina/v-instituti-patona-pravoohoronci-vipadkovo-natrapili-nanelegalnu-fabriku-bitkoyiniv-974142.html

9. Про Національний банк України: Закон України від 20 травня 1999 року № 679-XIV.

10. Спільна заява фінансових регуляторів щодо статусу криптовалют в Україні. https://bank.gov.ua/control/uk/publish/article?art_id=59735329

11. Insights. The 2021 Global Crypto Adoption Index: Worldwide Adoption Jumps Over 880\% With P2P Platforms Driving Cryptocurrency Usage in Emerging Markets. https://blog.chainalysis.com/reports/2021-global-crypto-adoption-index

12.Insights. The 2020 Global Crypto Adoption Index: Cryptocurrency is a Global Phenomenon. https://blog.chainalysis.com/reports/2020-global-cryptocurrency-adoption-index-2020

13. Insights. 2021. Bitcoin Gains by Country: Who Benefited the Most from the 2020 Boom? https://blog.chainalysis.com/reports/bitcoin-gains-by-country-2020.

14. Кухарєва О.О. Тенденції зовнішньоекономічної безпеки України // Бізнеснавігатор. - Випуск 3 (64) (2021). - С. 75-79.

\section{References:}

1. Volosovych, S.V. (2016). Virtualjna valjuta: ghlobalizacijni vyklyky i perspektyvy rozvytku [Virtual currency: globalization challenges and development prospects]. Naukovyj zhurnal "Ekonomika Ukrajiny" - Scientific journal "Economy of Ukraine", 4(653), 68-78 [in Ukrainian].

2. Malynovsjka, A.M. (2019). Virtualjni valjuty: poshyrennja ta peredumovy do vyznachennja [Virtual currencies: distribution and preconditions for definition]. Visnyk ekonomichnoji nauky - Bulletin of Economic Science, 2, 165-169 [in Ukrainian].

3. Osoblyvosti funkcionuvannja virtualjnykh kryptovaljut: ekonomichnyj aspekt [Features of the operation of virtual cryptocurrencies: economic aspect]. www.global-national.in.ua. Retrieved from http://www.global-national.in.ua/archive/14-2016/152.pdf [in Ukrainian].

4. Rubanov P.M. (2015). Rozmezhuvannja sutnosti ponjatj "elektronni ghroshi”, "virtualjni ghroshi" ta "kryptovaljuty" [Distinguishing the essence of the concepts of "electronic money", "virtual money" and "cryptocurrency"]. Efektyvna ekonomika - Efficient econom, 4. www.economy. nayka.com.ua. Retrieved from http://www.economy.nayka.com.ua/?op=1\&z=6026 [in Ukrainian]. 
5. Virtualjni ghroshi v Ukrajini: chy potribno leghalizuvaty kryptovaljutu [Virtual money in Ukraine: whether it is necessary to legalize cryptocurrency]. www.slovoidilo.ua. Retrieved from https://www.slovoidilo.ua/2019/11/19/pogljad/ekonomika/virtualni-hroshi-ukrayini-chypotribnolehalizuvaty-kryptovalyutu [in Ukrainian].

6. COINCAP. coincap.io. Retrieved from https://coincap.io/ [in English].

7. BITCOIN. bitcoin.org. Retrieved from https://bitcoin.org/uk/ [in English].

8. V instytuti Patona pravookhoronci vypadkovo natrapyly na neleghaljnu "fabryku bitkojiniv" [At the Paton Institute, law enforcement officers stumbled upon an illegal "bitcoin factory"]. TSN. tsn.ua. Retrieved from https://tsn.ua/ukrayina/v-instituti-patona-pravoohoroncivipadkovo natrapili-na-nelegalnu-fabriku-bitkoyiniv-974142.html [in Ukrainian].

9. Zakon Ukrajiny "Pro Nacionaljnyj bank Ukrajiny" : vid 20 travnja 1999 roku № 679-XIV [Law of Ukraine "On the National Bank of Ukraine" from May 20, 1999 № 679-XIV.] zakon.rada.gov.ua. Retrieved from https://zakon.rada.gov.ua/laws/show/679-14\#Text [in Ukrainian].

10. Spiljna zajava finansovykh reghuljatoriv shhodo statusu kryptovaljut v Ukrajini [Joint statement of financial regulators on the status of cryptocurrencies in Ukraine]. bank.gov.ua. Retrieved from https://bank.gov.ua/control/uk/publish/article?art_id=59735329 [in Ukrainian].

11. Insights. The 2021 Global Crypto Adoption Index: Worldwide Adoption Jumps Over 880\% With P2P Platforms Driving Cryptocurrency Usage in Emerging Markets. blog.chainalysis.com. Retrieved from https://blog.chainalysis.com/reports/2021-global-cryptoadoption-index [in English].

12. Insights. The 2020 Global Crypto Adoption Index: Cryptocurrency is a Global Phenomenon. blog.chainalysis.com. Retrieved from https://blog.chainalysis.com/reports/2020global-cryptocurrency-adoption-index-2020 [in English].

13. Insights. 2021. Bitcoin Gains by Country: Who Benefited the Most from the 2020 Boom? blog.chainalysis.com. Retrieved from https://blog.chainalysis.com/reports/bitcoin-gainsby-country-2020 [in English].

14. Kuhareva, O.O. (2021). Tendenciï zovnishn'oekonomichnoï bezpeki Ukraïni [Trends in foreign economic security of Ukraine]. Biznes-navigator - Business Navigator, 3 (64) (2021), 75 79 [in Ukrainian]. 